\title{
Two New Supramolecular Assemblies Obtained by Reaction Between Saccharin and Long-chain Diamines
}

\author{
Eduardo E. Castellano ${ }^{\mathrm{a}}$, Oscar E. Piro ${ }^{\mathrm{b}}$, Beatriz S. Parajón-Costa ${ }^{\mathrm{c}}$, and Enrique J. Baran ${ }^{\mathrm{c}}$ \\ ${ }^{a}$ Instituto de Fisica de Sâo Carlos, Universidade de Sâo Paulo, 13560 Sāo Carlos (SP), Brazil \\ ${ }^{\mathrm{b}}$ Departamento de Física and Instituto IFLP (CONICET). Facultad de Ciencias Exactas. Universidad \\ Nacional de La Plata, 1900 La Plata, Argentina \\ c Centro de Química Inorgánica (CEQUINOR, CONICET/UNLP), Facultad de Ciencias Exactas, \\ Universidad Nacional de La Plata. C. Correo 962. 1900 La Plata. Argentina
}

Reprint requests to Dr. E. J. Baran. E-mail: baran@quimica.unlp.edu.ar

Z. Naturforsch. 2009, 64b, 1041 - 1045; received May 22. 2009

\begin{abstract}
The crystal structures of heptamethylenediammonium bis(saccharinate) monohydrate, $\left[\mathrm{H}_{3} \mathrm{~N}\right.$ $\left.\left(\mathrm{CH}_{2}\right)_{7}-\mathrm{NH}_{3}\right](\mathrm{sac})_{2} \cdot \mathrm{H}_{2} \mathrm{O}(\mathbf{1})$ and octamethylenediammonium bis (saccharinate) hemihydrate. $\left[\mathrm{H}_{3} \mathrm{~N}\right.$ $\left.\left(\mathrm{CH}_{2}\right)_{8}-\mathrm{NH}_{3}\right]\left(\mathrm{sac}_{2} \cdot 0.5 \mathrm{H}_{2} \mathrm{O}(2)\right.$, were determined by single-crystal X-ray diffraction methods. Compound 1 crystallizes in the triclinic space group $P \overline{1}$ with 2 molecules per unit cell, and $\mathbf{2}$ in the monoclinic space group $P 2{ }_{1} / a$ with $Z=4$. The saccharinate moiety is planar in both compounds presenting bonding characteristics comparable to those found in other saccharinate salts. The ionic crystals are further stabilized by an extensive H-bonding network. which links the anions and cations into an infinite three-dimensional supramolecular assembly. The FTIR spectra of the adducts are briefly discussed in comparison with those of the constituent molecules.
\end{abstract}

Key words: Heptamethylenediammonium Bis(saccharinate) Monohydrate, Octamethylenediammonium Bis(saccharinate) Hemihydrate. Crystal Structures, Supramolecular Adducts. IR Spectra

\section{Introduction}

During the last years a number of interesting supramolecular structures of organic salts containing saccharin and different organic bases have been prepared and characterized [1-6], and we have extended these studies to some related species generated from thiosaccharin instead of saccharin $[7,8]$. With the only exception of 1,6-hexanediamine $[1,7]$, in all the structures reported so far relatively small organic bases were always present. To explore the possibility of similar supramolecular assemblies with longer-chain diamines, we have prepared and characterized two new systems of this type containing 1,7-heptanediamine and 1,8-octanediamine, and the results are reported here.

\section{Results and Discussion \\ Crystal and molecular structures}

Fig. 1 shows an ORTEP-3 [9] drawing of the structure of $\left[\mathrm{H}_{3} \mathrm{~N}-\left(\mathrm{CH}_{2}\right)_{7}-\mathrm{NH}_{3}\right](\mathrm{sac})_{2} \cdot \mathrm{H}_{2} \mathrm{O}(\mathbf{1})$. Selected bond lengths and angles are shown in Table 1.
As expected, both $\mathrm{C}_{6} \mathrm{H}_{4}(\mathrm{C}=\mathrm{O}) \mathrm{SO}_{2} \mathrm{~N}^{-}$saccharinate anions are planar (r.m.s. deviation of atoms from the corresponding least-squares plane are less than $0.01 \mathrm{~A})$. They are nearly perpendicular to each other [dihedral angle $\left.=93.09(5)^{\circ}\right]$, with the $\left[\mathrm{H}_{3} \mathrm{~N}-\left(\mathrm{CH}_{2}\right)_{7}-\right.$ $\left.\mathrm{NH}_{3}\right]^{2+}$ cation lying along the corner defined by the saccharinate planes. By translation along the crystallographic $a$ and $b$ axes an electrically neutral slab parallel to the $a b$ plane with a wine cellar-like structure is generated, where the cellar walls are defined by the saccharinate anions and the stored bottles by the cations. The slab is further stabilized at its surfaces by $\mathrm{NH}_{3} \ldots$ $\mathrm{N}$ ( $\mathrm{sac}$ ) and $\mathrm{N}-\mathrm{H}$... O (sulfoxide) bonds between the enclosed cations and their surrounding saccharinate anions. Neighboring slabs along the $c$ axes, in turn, are linked to each other through $\mathrm{NH}_{3} \cdots \mathrm{O}$ (carb), $\mathrm{NH}_{3} \cdots \mathrm{O}$ (sulf) and bridging $\mathrm{NH}_{3} \cdots \mathrm{OW}-\mathrm{H} \cdots \mathrm{N}(\mathrm{sac}$ ) and (sac)$\mathrm{N} \cdot \mathrm{H}-\mathrm{H}-\mathrm{Ow}-\mathrm{H} \cdot \mathrm{O}$ (sulf) bonds. Fig. 2 presents an ORTEP-3 [9] drawing of these interactions. Further details of the H-bonding network are provided in the deposited material.

An ORTEP-3 [9] drawing of the structure of $\left[\mathrm{H}_{3} \mathrm{~N}\right.$ $\left.\left(\mathrm{CH}_{2}\right)_{8}-\mathrm{NH}_{3}\right](\mathrm{sac})_{2} \cdot 0.5 \mathrm{H}_{2} \mathrm{O}(2)$ is shown in Fig. 3 
Table 1. Selected bond lengths (A) and angles (deg) in $\left[\mathrm{H}_{3} \mathrm{~N}-\left(\mathrm{CH}_{2}\right)_{7}-\mathrm{NH}_{3}\right]\left(\mathrm{sac}_{2} \cdot \mathrm{H}_{2} \mathrm{O}(\mathbf{1})\right.$.

\begin{tabular}{llll}
\hline $\mathrm{N}(1)-\mathrm{C}(1)$ & $1.490(3)$ & $\mathrm{C}(15)-\mathrm{C}(16)$ & $1.379(4)$ \\
$\mathrm{N}(2)-\mathrm{C}(7)$ & $1.476(4)$ & $\mathrm{C}(25)-\mathrm{C}(26)$ & $1.376(4)$ \\
$\mathrm{C}(1)-\mathrm{C}(2)$ & $1.510(3)$ & $\mathrm{C}(16) \mathrm{C}(17)$ & $1.382(3)$ \\
$\mathrm{C}(4)-\mathrm{C}(5)$ & $1.520(4)$ & $\mathrm{O}(1 \mathrm{~W})-\mathrm{H}(1 \mathrm{~W})$ & $0.826(19)$ \\
$\mathrm{C}(6)-\mathrm{C}(7)$ & $1.498(4)$ & $\mathrm{O}(1 \mathrm{~W})-\mathrm{H}(2 \mathrm{~W})$ & $0.83(2)$ \\
$\mathrm{S}(1)-\mathrm{O}(13)$ & $1.438(2)$ & $\mathrm{S}(2)-\mathrm{O}(23)$ & $1.439(2)$ \\
$\mathrm{S}(1)-\mathrm{O}(12)$ & $1.439(2)$ & $\mathrm{S}(2)-\mathrm{O}(22)$ & $1.445(2)$ \\
$\mathrm{S}(1)-\mathrm{N}(11)$ & $1.608(2)$ & $\mathrm{S}(2)-\mathrm{N}(21)$ & $1.589(2)$ \\
$\mathrm{S}(1)-\mathrm{C}(17)$ & $1.759(2)$ & $\mathrm{S}(2)-\mathrm{C}(27)$ & $1.761(2)$ \\
$\mathrm{C}(11) \mathrm{O}(11)$ & $1.179(3)$ & $\mathrm{C}(21)-\mathrm{O}(21)$ & $1.237(3)$ \\
$\mathrm{C}(11)-\mathrm{N}(11)$ & $1.388(3)$ & $\mathrm{C}(21)-\mathrm{N}(21)$ & $1.355(3)$ \\
$\mathrm{C}(11)-\mathrm{C}(12)$ & $1.528(3)$ & $\mathrm{C}(21)-\mathrm{C}(22)$ & $1.504(3)$ \\
$\mathrm{C}(12)-\mathrm{C}(17)$ & $1.372(3)$ & $\mathrm{C}(22)-\mathrm{C}(27)$ & $1.376(4)$ \\
$\mathrm{C}(12)-\mathrm{C}(13)$ & $1.380(4)$ & $\mathrm{C}(22)-\mathrm{C}(23)$ & $1.386(3)$ \\
$\mathrm{N}(1)-\mathrm{C}(1)-\mathrm{C}(2)$ & $111.0(2)$ & $\mathrm{N}(2)-\mathrm{C}(7)-\mathrm{C}(6)$ & $113.7(3)$ \\
$\mathrm{C}(1)-\mathrm{C}(2)-\mathrm{C}(3)$ & $112.6(2)$ & $\mathrm{C}(7)-\mathrm{C}(6)-\mathrm{C}(5)$ & $115.5(3)$ \\
$\mathrm{O}(13)-\mathrm{S}(1)-\mathrm{O}(12)$ & $114.14(14)$ & $\mathrm{O}(23)-\mathrm{S}(2)-\mathrm{O}(22)$ & $112.14(11)$ \\
$\mathrm{O}(11)-\mathrm{C}(11)-\mathrm{N}(11)$ & $125.7(2)$ & $\mathrm{O}(21)-\mathrm{C}(21)-\mathrm{N}(21)$ & $123.8(2)$ \\
$\mathrm{S}(1)-\mathrm{N}(11)-\mathrm{C}(11)$ & $113.46(17)$ & $\mathrm{S}(2)-\mathrm{N}(21)-\mathrm{C}(21)$ & $111.48(17)$ \\
$\mathrm{C}(13) \mathrm{C}(12)-\mathrm{C}(11)$ & $127.3(2)$ & $\mathrm{C}(23)-\mathrm{C}(22)-\mathrm{C}(21)$ & $129.9(2)$ \\
$\mathrm{H}(\mathrm{W})-\mathrm{O}(\mathrm{W})-\mathrm{H}(\mathrm{W})$ & $96(5)$ & $\mathrm{C}(26)-\mathrm{C}(27)-\mathrm{S}(2)$ & $129.7(2)$ \\
\hline
\end{tabular}

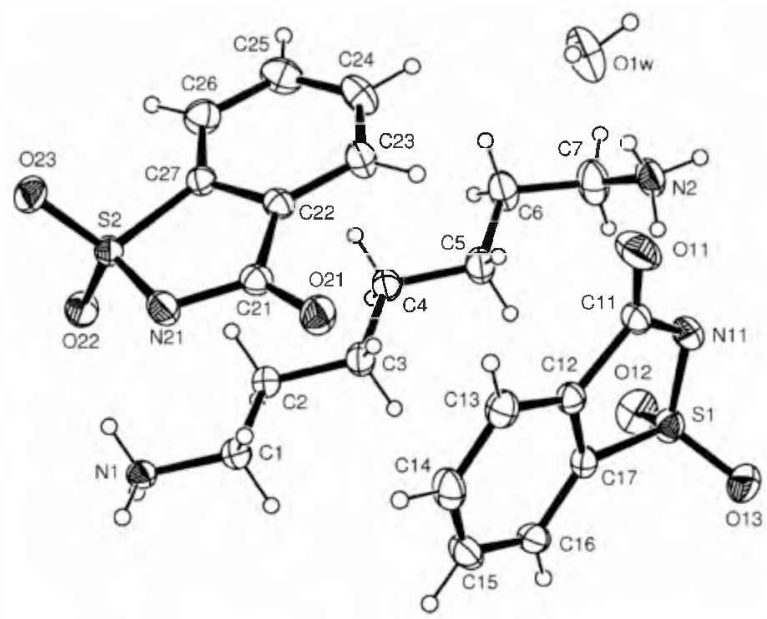

Fig. 1. Molecular structure of $\left[\mathrm{H}_{3} \mathrm{~N}-\left(\mathrm{CH}_{2}\right)_{7}-\mathrm{NH}_{3}\right](\mathrm{sac})_{2}$. $\mathrm{H}_{2} \mathrm{O}$ (1) in the crystal showing the labeling of the non- $\mathrm{H}$ atoms (displacement ellipsoids at the $30 \%$ probability level).

and selected bond lengths and angles are shown in Table 2.

As for $\left[\mathrm{H}_{3} \mathrm{~N}-\left(\mathrm{CH}_{2}\right)_{7}-\mathrm{NH}_{3}\right](\mathrm{sac})_{2} \cdot \mathrm{H}_{2} \mathrm{O}(\mathbf{1})$, both saccharinate anions are planar (r. m.s. deviation of atoms from the least-squares plane less than $0.018 \mathrm{~A}$ ) and present a similar supramolecular arrangement around the longer $\left[\mathrm{H}_{3} \mathrm{~N}-\left(\mathrm{CH}_{2}\right)_{8}-\mathrm{NH}_{3}\right]^{2+}$ cation. In fact, the two saccharinate planes now subtend an angle of $100.89(7)^{\circ}$ with each other and bind the cation which extends along the edge defined by the planes. The symmetry of the crystal lattice gives rise to neutral
Table 2. Selected bond lengths (A) and angles (deg) in $\left[\mathrm{H}_{3} \mathrm{~N}-\left(\mathrm{CH}_{2}\right)_{8}-\mathrm{NH}_{3}\right](\mathrm{sac})_{2} \cdot 0.5 \mathrm{H}_{2} \mathrm{O}(2)$.

\begin{tabular}{llll}
\hline $\mathrm{N}(1)-\mathrm{C}(1)$ & $1.489(4)$ & $\mathrm{C}(15)-\mathrm{C}(16)$ & $1.389(6)$ \\
$\mathrm{N}(2)-\mathrm{C}(8)$ & $1.478(5)$ & $\mathrm{C}(25)-\mathrm{C}(26)$ & $1.378(6)$ \\
$\mathrm{C}(1) \mathrm{C}(2)$ & $1.502(5)$ & $\mathrm{C}(16) \mathrm{C}(17)$ & $1.379(5)$ \\
$\mathrm{C}(3)-\mathrm{C}(4)$ & $1.520(5)$ & $\mathrm{C}(26)-\mathrm{C}(27)$ & $1.383(5)$ \\
$\mathrm{C}(7)-\mathrm{C}(8)$ & $1.551(7)$ & $\mathrm{C}(24)-\mathrm{C}(25)$ & $1.366(6)$ \\
$\mathrm{S}(1)-\mathrm{O}(13)$ & $1.446(2)$ & $\mathrm{S}(2)-\mathrm{O}(23)$ & $1.443(3)$ \\
$\mathrm{S}(1)-\mathrm{O}(12)$ & $1.436(2)$ & $\mathrm{S}(2)-\mathrm{O}(22)$ & $1.437(3)$ \\
$\mathrm{S}(1)-\mathrm{N}(11)$ & $1.595(3)$ & $\mathrm{S}(2)-\mathrm{N}(21)$ & $1.612(3)$ \\
$\mathrm{S}(1)-\mathrm{C}(17)$ & $1.764(3)$ & $\mathrm{S}(2)-\mathrm{C}(27)$ & $1.764(3)$ \\
$\mathrm{C}(11) \mathrm{O}(11)$ & $1.244(4)$ & $\mathrm{C}(21) \mathrm{O}(21)$ & $1.246(4)$ \\
$\mathrm{C}(11)-\mathrm{N}(11)$ & $1.348(4)$ & $\mathrm{C}(21)-\mathrm{N}(21)$ & $1.340(5)$ \\
$\mathrm{C}(11)-\mathrm{C}(12)$ & $1.500(4)$ & $\mathrm{C}(21)-\mathrm{C}(22)$ & $1.493(4)$ \\
$\mathrm{C}(12)-\mathrm{C}(17)$ & $1.379(5)$ & $\mathrm{C}(22)-\mathrm{C}(27)$ & $1.378(5)$ \\
$\mathrm{C}(12)-\mathrm{C}(13)$ & $1.381(5)$ & $\mathrm{C}(22)-\mathrm{C}(23)$ & $1.379(5)$ \\
$\mathrm{N}(1)-\mathrm{C}(1)-\mathrm{C}(2)$ & $111.4(3)$ & $\mathrm{N}(2) \mathrm{C}(8)-\mathrm{C}(7)$ & $112.1(4)$ \\
$\mathrm{C}(1)-\mathrm{C}(2)-\mathrm{C}(3)$ & $111.9(3)$ & $\mathrm{C}(8)-\mathrm{C}(7)-\mathrm{C}(6)$ & $122.0(7)$ \\
$\mathrm{O}(13)-\mathrm{S}(1)-\mathrm{O}(12)$ & $112.48(15)$ & $\mathrm{O}(23)-\mathrm{S}(2)-\mathrm{O}(22)$ & $113.53(18)$ \\
$\mathrm{O}(11)-\mathrm{C}(11)-\mathrm{N}(11)$ & $123.5(3)$ & $\mathrm{O}(21)-\mathrm{C}(21)-\mathrm{N}(21)$ & $124.8(3)$ \\
$\mathrm{S}(1)-\mathrm{N}(11)-\mathrm{C}(11)$ & $111.0(2)$ & $\mathrm{S}(2)-\mathrm{N}(21)-\mathrm{C}(21)$ & $111.5(2)$ \\
$\mathrm{C}(13) \mathrm{C}(12)-\mathrm{C}(11)$ & $129.7(3)$ & $\mathrm{C}(23)-\mathrm{C}(22)-\mathrm{C}(21)$ & $128.3(3)$ \\
$\mathrm{C}(16)-\mathrm{C}(17)-\mathrm{S}(1)$ & $130.2(3)$ & $\mathrm{C}(26)-\mathrm{C}(27)-\mathrm{S}(2)$ & $131.3(3)$ \\
\hline
\end{tabular}

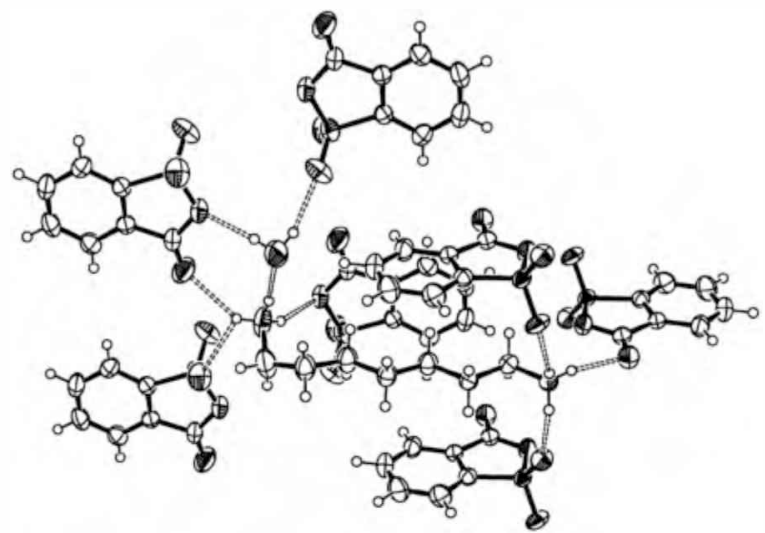

Fig. 2. Molecular packing of $\left[\mathrm{H}_{3} \mathrm{~N}-\left(\mathrm{CH}_{2}\right)_{7}-\mathrm{NH}_{3}\right](\mathrm{sac})_{2} \cdot \mathrm{H}_{2} \mathrm{O}$ $(1)$ in the crystal. Sulfur, oxygen and nitrogen atoms are indicated by hatched ellipsoids and carbon atoms by crossed ones. Hydrogen bonds are denoted by dashed lines.

slabs parallel to the crystallographic $a b$ plane which stack along the $c$ axes, with the cellar-like structure described for 1. As for this salt, each slab is further stabilized at its surfaces by $\mathrm{NH}_{3} \cdots \mathrm{N}(\mathrm{sac})$ and $\mathrm{NH}_{3} \ldots \mathrm{O}$ (sulf) bonds between the enclosed cations and their surrounding saccharinate anions. Neighboring slabs along the $c$ axes, in turn, are linked to each other through $\mathrm{NH}_{3} \ldots \mathrm{O}$ (carb) and $\mathrm{NH}_{3} \ldots \mathrm{O}$ (sulf) interactions. Further details of the $\mathrm{H}$-bonding network are provided in the deposited material.

Finally, a comparison of bond lengths and angles of the two described adducts with those found 


\begin{tabular}{|c|c|c|c|c|c|}
\hline $\mathrm{NaSac} \cdot \mathrm{H}_{2} \mathrm{O}$ & $\mathrm{NH}_{2}\left(\mathrm{CH}_{2}\right)_{7} \mathrm{NH}_{2}$ & $\mathrm{NH}_{2}\left(\mathrm{CH}_{2}\right)_{8} \mathrm{NH}_{2}$ & 1 & 2 & Assignment \\
\hline & \multirow[t]{3}{*}{$3320 \mathrm{~s}$} & $3353 \mathrm{~m}$ & & & $v_{\mathrm{as}}\left(\mathrm{NH}_{2}\right)$ \\
\hline & & \multirow[t]{2}{*}{$3270 \mathrm{sh}$} & & & $v_{\mathrm{S}}\left(\mathrm{NH}_{2}\right)$ \\
\hline & & & 3202 vs & $3170 \mathrm{vs}$ & $v\left(\mathrm{NH}_{3}{ }^{+}\right)$ \\
\hline & $2927 \mathrm{~s}$ & $2924 \mathrm{~s}$ & $2935 \mathrm{~s}$ & $2933 \mathrm{~s}$ & $v_{\mathrm{as}}\left(\mathrm{CH}_{2}\right)$ \\
\hline & \multirow[t]{2}{*}{$2856 \mathrm{~m}$} & \multirow[t]{2}{*}{$2853 \mathrm{~m}$} & $2860 \mathrm{~m}$ & $2863 \mathrm{~m}$ & $v_{\mathrm{s}}\left(\mathrm{CH}_{2}\right)$ \\
\hline & & & $2039 \mathrm{~m}$ & $2054 \mathrm{~m}$ & see text \\
\hline $1642 \mathrm{vs}$ & & \multirow{7}{*}{$1580 \mathrm{vs}$} & $1629 \mathrm{vs}$ & $1632 \mathrm{vs}$ & $v(\mathrm{C}=\mathrm{O})$ \\
\hline \multirow[t]{2}{*}{$1590 \mathrm{~s}$} & \multirow{6}{*}{1577 vs } & & $1585 \mathrm{~s}$ & $1581 \mathrm{~s}$ & $v(\mathrm{C}-\mathrm{C})+\delta_{\mathrm{as}}\left(\mathrm{NH}_{3}{ }^{+}\right)$ \\
\hline & & & & & $\delta_{\text {sciss }}\left(\mathrm{NH}_{2}\right)$ \\
\hline $1460 \mathrm{~m}$ & & & $1463 \mathrm{~m}$ & $1462 \mathrm{~m}$ & $v(\mathrm{C}-\mathrm{C})$ \\
\hline $1336 \mathrm{~m}$ & & & $1334 \mathrm{~m}$ & $1335 \mathrm{~m}$ & $v_{\mathrm{S}}(\mathrm{CNS})$ \\
\hline $1258 \mathrm{vs}$ & & & $1260 \mathrm{vs}$ & $1259 \mathrm{vs}$ & $v_{\mathrm{as}}\left(\mathrm{SO}_{2}\right)$ \\
\hline \multirow[t]{2}{*}{$1150 \mathrm{vs}$} & & & $1146 \mathrm{vs}$ & $1141 \mathrm{vs}$ & $v_{\mathrm{s}}\left(\mathrm{SO}_{2}\right)$ \\
\hline & \multirow[t]{4}{*}{$1085 \mathrm{w}$} & \multirow[t]{4}{*}{$1044 \mathrm{~m}$} & $1052 \mathrm{~s}$ & $1051 \mathrm{~s}$ & $v(\mathrm{CN})_{\text {amine }}$ \\
\hline $970 \mathrm{~s}$ & & & & $980 \mathrm{w}$ & $\gamma(\mathrm{CH})$ \\
\hline $950 \mathrm{~m}$ & & & $956 \mathrm{~s}$ & $943 \mathrm{~m}$ & $v_{\mathrm{as}}(\mathrm{CNS})$ \\
\hline $794 w$ & & & $796 \mathrm{~m}$ & $798 w$ & $\delta(\mathrm{CO})$ \\
\hline & \multirow[t]{4}{*}{$821 \mathrm{w}$} & \multirow[t]{4}{*}{$818 \mathrm{~m}$} & & & $\delta_{\text {wagg }}\left(\mathrm{NH}_{2}\right)$ \\
\hline $677 \mathrm{~m}$ & & & $681 \mathrm{~m}$ & $680 \mathrm{~m}$ & $\delta(\mathrm{CCC})$ \\
\hline \multirow[t]{2}{*}{$610 \mathrm{~m}$} & & & $604 \mathrm{~s}$ & $606 \mathrm{~s}$ & $\delta\left(\mathrm{SO}_{2}\right)$ \\
\hline & & & $486 \mathrm{~m}$ & $481 \mathrm{w}$ & $\tau\left(\mathrm{NH}_{3}{ }^{+}\right)$ \\
\hline
\end{tabular}

Table 3. Assignment of some of the most characteristic IR bands of saccharinate in the sodium salt. of the two free amines and of the two new adducts 1 and 2 (band positions in $\left.\mathrm{cm}^{-1}\right){ }^{\text {a }}$

a vs, very strong; $s$, strong; $m$ medium; w, weak; sh, shoulder.

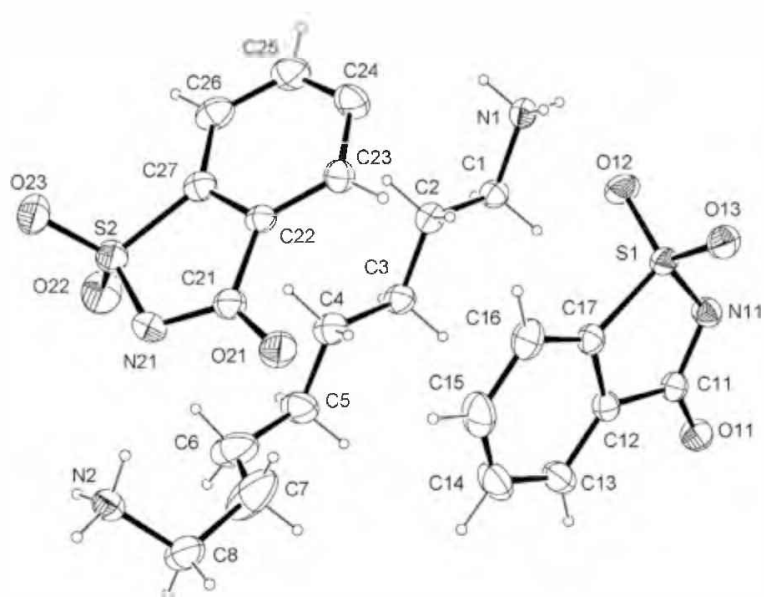

Fig. 3. Molecular structure of $\left[\mathrm{H}_{3} \mathrm{~N}-\left(\mathrm{CH}_{2}\right)_{8}-\mathrm{NH}_{3}\right](\mathrm{sac})_{2}$. $0.5 \mathrm{H}_{2} \mathrm{O}(2)$ in the crystal showing the labeling of the non- $\mathrm{H}$ atoms (displacement ellipsoids at the $30 \%$ probability level).

in some ionic saccharinates, for example $\mathrm{Na}_{7}\left(\mathrm{C}_{7} \mathrm{H}_{4}\right.$ $\left.\mathrm{NO}_{3} \mathrm{~S}\right) \cdot 2 / 3 \mathrm{H}_{2} \mathrm{O}$ [10], $\mathrm{Mg}\left(\mathrm{C}_{7} \mathrm{H}_{4} \mathrm{NO}_{3} \mathrm{~S}\right)_{2} \cdot 7 \mathrm{H}_{2} \mathrm{O}$ [10] or $\mathrm{K}_{2} \mathrm{Na}\left(\mathrm{C}_{7} \mathrm{H}_{4} \mathrm{NO}_{3} \mathrm{~S}\right)_{3} \cdot \mathrm{H}_{2} \mathrm{O}[11]$, shows very similar values for all of them. A further comparison with data of free saccharin [12] shows in all cases the expected shortening of the $\mathrm{C}-\mathrm{N}$ and $\mathrm{S}-\mathrm{N}$ bonds upon deprotonation [13], whereas the $\mathrm{C}-\mathrm{O}$ and $\mathrm{S}-\mathrm{O}$ bonds are less affected than expected.

\section{Infrared spectra}

We have measured the FTIR spectra of the two new adducts as well as those of the two free diamines em- ployed in their synthesis. The assignment of some of the most characteristic bands of these molecules was performed with the aid of standard references $[14,15]$. In Table 3 we compare the most characteristic IR bands of the adducts, the diamines and the saccharinate in its sodium salt [16].

As it can be appreciated, the typical $v(\mathrm{C}=\mathrm{O})$ stretching vibration of the saccharinate anion is slightly displaced to lower frequencies upon adduct formation, surely due to the involvement of this group in hydrogen bonding. The stretching vibrations of the $\mathrm{SO}_{2}$ groups are less affected, although the $v_{\mathrm{s}}\left(\mathrm{SO}_{2}\right)$ mode shows a definite displacement to lower frequencies. Skeletal saccharinate bands are practically not affected.

As expected, most of the typical amine $\mathrm{NH}_{2}$ vibrations are replaced by $\mathrm{NH}_{3}{ }^{+}$vibrations in the adducts. Interestingly, a combination band, which is typical and often appears in the case of ammine salts [14], could be clearly identified as a medium intensity band at $2039 \mathrm{~cm}^{-1}$ (adduct 1 ) and $2054 \mathrm{~cm}^{-1}$ (adduct 2).

\section{Experimental Section}

Synthesis of the adducts

All reagents were commercially available (saccharin and diamines from Aldrich. solvents from Merck) and were used as purchased. The adducts were obtained by addition of $1.0 \mathrm{mmol}$ of the respective diamine to a methanolic solution $(30 \mathrm{~mL}$ ) containing $2.0 \mathrm{mmol}$ of saccharin. The mixtures were heated with stirring for $15 \mathrm{~min}$ at $40 \mathrm{C}$. The re- 
Table 4. Crystal and structure refinement data of $\left[\mathrm{H}_{3} \mathrm{~N}-\left(\mathrm{CH}_{2}\right)_{7}-\mathrm{NH}_{3}\right](\mathrm{sac})_{2} \cdot \mathrm{H}_{2} \mathrm{O}$ (1) and $\mid \mathrm{H}_{2} \mathrm{~N}-\mathrm{CH}_{2} \mathrm{ix}_{\mathbf{x}}$ $\left.\mathrm{NH}_{3}\right](\mathrm{sac})_{2} \cdot 0.5 \mathrm{H}_{2} \mathrm{O}(2)$.

\begin{tabular}{lll}
\hline & $\mathbf{1}$ & $\mathbf{2}$ \\
\hline Formula & $\mathrm{C}_{21} \mathrm{H}_{30} \mathrm{~N}_{4} \mathrm{O}_{7} \mathrm{~S}_{2}$ & $\mathrm{C}_{22} \mathrm{H}_{31} \mathrm{~N}_{4} \mathrm{O}_{6.5} \mathrm{~S}_{2}$ \\
Formula weight & 514.61 & 519.63 \\
Crystal system & triclinic & monoclinic \\
Space group & $P 1$ & $P_{1} / a$ \\
$a, \AA$ & $7.9404(4)$ & $16.5660(5)$ \\
$b, \AA$ & $8.2119(5)$ & $8.0522(3)$ \\
$c$, A & $18.8831(7)$ & $19.5757(6)$ \\
$\alpha$, deg & $98.036(3)$ & 90 \\
$\beta$, deg & $92.324(3)$ & $106.107(2)$ \\
$\gamma$, deg & $92.821(2)$ & 90 \\
$V, \AA^{3}$ & $1216.32(11)$ & $2508.75(14)$ \\
$D$ c, g cm & 1.405 & 1.376 \\
$Z$ & 2 & 4 \\
$F(000)$, e & 544 & 1100 \\
$\theta$ range data collection, deg & $2.51-25.93$ & $2.49-26.00$ \\
Index ranges $h k l$ & $-9<h<8$ & $-20 \leq h \leq 20$ \\
& $-9 \leq k \leq 10$ & $-9 \leq k \leq 7$ \\
Reflections coll. / indep. & $-23<l<23$ & $-24 \leq l \leq 22$ \\
$R_{\text {int }}$ & $10513 / 4694$ & $16663 / 4912$ \\
Observ, reflect. $\mid I>2 \sigma(I)]$ & 0.0600 & 0.0655 \\
Data / restraints/ ref. param. & 4482 & 3423 \\
Final $R 1 /$ w $R 2[I>2 \sigma(\mathrm{I})]$ & $0.0488 / 0.1179$ & $0.0651 / 0.1702$ \\
Final $R 1 /$ w $R 2$ (all data) & $0.0745 / 0.1305$ & $0.0996 / 0.1952$ \\
Goodness-of-fit on $F^{2}$ & 1.041 & 1.034 \\
$\Delta \rho_{\text {fin }}$ (max / min), e A ${ }^{-3}$ & $0.38 /-0.51$ & $1.26 /-0.88$ \\
\hline
\end{tabular}

sulting solutions were filtered. and the filtrates were slowly evaporated at r.t. After a few days an abundant quantity of crystalline material precipitated from the solution. Similar assays performed under the same conditions with 1,9-nonanediamine, and using a variety of solvents and solvent mixtures. were unsuccessful as it was impossible to isolate single crystals adequate for structural work from the solid precipitates.

\section{Crystal structure determination}

$\mathrm{X}$-Ray diffraction data were collected on an Enraf-Nonius Kappa-CCD diffractometer at $293(2) \mathrm{K}$ with graphitemonochromatized $\mathrm{MoK}_{\alpha}(\lambda=0.71073 \mathrm{~A})$ radiation. Colorless crystals of dimensions $0.19 \times 0.12 \times 0.08 \mathrm{~mm}^{3}$ (1) and $0.25 \times 0.18 \times 0.08 \mathrm{~mm}^{3}(2)$ were used in the experi- ments. Crystal data and refinement results are summarized in Table 4. The final unit cell parameters were based on all reflections. Data collections were made using the program COLLECT [17]; integration and scaling of the reflections were performed with the HKL DENZO-SCALEPACK system of programs [18]. Absorption corrections were deemed unnecessary. The structures were solved by Direct Methods with SHELXS-97 [19], and the molecular model was refined by full-matrix least-squares on $F^{2}$ by means of SHELXL97 [20]. All hydrogen atoms were stereochemically positioned and refined with the riding model. except the water hydrogens, which in the case of compound $\mathbf{1}$ were found in a difference map and refined restrained to a target $\mathrm{O}-\mathrm{H}$ distance of $0.82(2) \mathrm{A}$. In the case of compound 2 a disordered water molecule was modeled with an occupation factor of 0.5: its $\mathrm{H}$ atoms could not be located in the final difference map and were not included in the model. Besides, the diammonium cation in this same compound shows some degree of disorder at carbon atom $\mathrm{C} 7$ as indicated by a peak of $1.26 \mathrm{e} \mathrm{A}^{-3}$ in the final difference map. However, though attempts to model the disorder setting $\mathrm{C} 7$ in two different positions did improve the $R 1$ factor slightly, it did not produce a significantly better stereochemistry of this moiety, and the procedure was therefore discarded. As a consequence of this disorder, interatomic distances involving C7 are somewhat dubious.

CCDC 736974 (1) and CCDC 736975 (2) contain the supplementary crystallographic data. These data can be obtained free of charge from The Cambridge Crystallographic Data Centre via www.ccdc.cam.ac.uk/data_request/cif.

\section{Spectroscopic measurements}

The infrared spectra of the two compounds, as well as those of the respective free diamines, were recorded in the spectral range between 4000 and $400 \mathrm{~cm}^{-1}$ on a FTIRBruker-EQUINOX-55 instrument, using $\mathrm{KBr}$ pellets.

\section{Acknowledgement}

This work has been supported by CONICET (Argentina). UNLP (Argentina) and FAPESP (Brazil). OEP, BSPC and EJB are members of the Research Career from CONICET.
[1] Z. L. Wang. L. H. Wei. M. X. Li. J. Y. Niu. Acta Crystallogr. 2006, E62, o1314-o1316.

[2] Z. L. Wang. L. H. Wei, M. X. Li, J. P. Wang, Acta Crystallogr. 2006, E62. o1800-o1801.

[3] Z. L. Wang, M. X. Li, L. H. Wei, J. P. Wang, Acta Crystallogr. 2006. E62. 02127-02128.

[4] Z. L. Wang, M. X. Li, L. H. Wei, J. P. Wang, Acta Crystallogr. 2006, E62, o2171-o2172.
[5] R. Banerjee. B. K. Saha. G. R. Desiraju. Acta Crystallogr. 2006, C62, o346-o349.

[6] Z. L. Wang, M. X. Li, L. H. Wei, J. P. Wang, Acta Crystallogr. 2006, E62, 02274-02275.

[7] E. J. Baran, O. E. Piro, J. Zinczuk, Z. Naturforsch. 2007. $62 b, 1530-1534$.

[8] O. E. Piro, J. Zinczuk, E. J. Baran, Z. Naturforsch. 2008. 63b, $877-879$. 
[9] C. K. Johnson, M. N. Burnett, ORTEP-3, Rep. ORNL6895, Oak Ridge National Laboratory, Oak Ridge. T. N (USA) 1996. Windows version: L. J. Farrugia, University of Glasgow, Glasgow, Scotland (U. K.) 1999. See also: L. J. Farrugia. J. Appl. Crystallogr. 1997, 30, 565.

[10] G. Jovanovski, B. Kamenar, Cryst. Struct. Comm. 1982, 11, 247-255.

[11] K. M. A. Malik. S.Z. Haider. M. A. Hossan. M. B. Hursthouse, Acta Crystallogr. 1984, C40, 1696-1698.

[12] J. L. Wardell, J. N. Low. Ch. Glidewell, Acta Crystal$\log r$. 2005, E61, o1944-o1946.

[13] P. Naumov, G. Jovanosvski, Struct. Chem. 2000, 11 , $19-33$.

[14] D. Lin-Vien, N. B. Colthup, W. G. Fateley, J. G. Grasselli. The Handbook of Infrared and Raman Characteristic Frequencies of Organic Molecules. Academic Press, Boston, 1991.
[15] B. Smith, Infrared Spectral Interpretation, CRC Press, Boca Raton. 1999.

[16] O. V. Quinzani, S. Tarulli, O. E. Piro, E. J. Baran. E. E. Castellano, Z. Naturforsch. 1997, 52b, 183-187.

[17] Collect, Nonius KappaCCD Software. Nonius BV. Delft (The Netherlands) 2000.

[18] HKL Denzo, Scalepack, Z. Otwinowski, W. Minor, in Methods in Enzymology. Vol. 276. Macromolecular Crystallography, Part A (Eds.: C. W. Carter Jr., R. M. Sweet), Academic Press. New York. 1997. pp. $307-326$.

[19] G. M. Sheldrick. SHELXS-97, Program for the Solution of Crystal Structures. University of Gottingen. Gottingen (Germany) 1997.

[20] G. M. Sheldrick, SHELXL-97. Program for the Refinement of Crystal Structures. University of Gottingen. Gottingen (Germany) 1997. See also: G. M. Sheldrick, Acta Crystallogr. 2008. A64, 112-122. 